\title{
Thermoregulation and activity pattern of the high-mountain lizard Phymaturus palluma (Tropiduridae) in Chile
}

\author{
Marcela A. Vidal 1, 5; Evelyn Habit ${ }^{2}$; Pedro Victoriano ${ }^{3}$; Angélica González-Gajardo ${ }^{4}$ \& Juan C. Ortiz ${ }^{3}$ \\ ${ }^{1}$ Laboratorio de Genómica y Biodiversidad, Departamento de Ciencias Básicas, Facultad de Ciencias, Universidad del Bío-Bío. \\ Casilla 447, Chillán, Chile. E-mail: marcela.vidal@gmail.com \\ 2 Unidad de Sistemas Acuáticos, Centro Eula, Universidad de Concepción. Casilla 160-C, Concepción, Chile. \\ ${ }^{3}$ Departamento de Zoología, Facultad de Ciencias Naturales y Oceanográficas, Universidad de Concepción. Casilla 160-C, \\ Concepción, Chile. \\ ${ }^{4}$ Centro de Estudios Avanzados en Ecología y Biodiversidad, Departamento de Ecología, Facultad de Ciencias Biológicas, \\ Pontificia Universidad Católica de Chile. Casilla 114-D, Santiago, Chile. \\ ${ }^{5}$ Corresponding author.
}

\begin{abstract}
Behavioral and physiological mechanisms of thermoregulation in ectotherms are conditioned by thermal constraints. These mechanisms may be even more restrictive when environmental conditions are unfavorable for individuals, especially when sexual dimorphism segregates the sexes spatially. In order to understand behavioral and physiological regulation mechanisms, we investigated the thermal biology of Phymaturus palluma (Molina, 1782), a sexually size dimorphic, high-mountain lizard that inhabits extreme climatic conditions. P. palluma showed a bimodal activity pattern, a major peak in the morning (11:00-13:30h) and in the afternoon (15:30-18:00 h). The lizards were more active when substrate temperatures were between 25 and $28^{\circ} \mathrm{C}$. The highest abundance was found around $27^{\circ} \mathrm{C}$ (between 11:00-12:30). Females showed greater activity than males in the early morning. Sub-adults and juveniles did not show differences in their activity pattern. There was a positive relationship between body temperature and air and substrate temperatures, suggesting typically thigmothermal regulation.
\end{abstract}

KEY WORDS. Age classes; daily activity; sexual dimorphism.

Thermorregulation influences physiological, behavioral and ecological features in ectotherms (AvEry 1982, BAuwens et al. 1996, Seebacker \& Franklin 2005). Behavioral mechanisms allow temperature regulation, including changes in activity times, the selection of thermally appropriate microhabitats, and postural adjustments (Porter \& Gates 1969, Huey \& Slatkin 1976, Dunham et al. 1989, Adolph 1990, Adolph \& Porter 1993, Hertz et al. 1993, Bauwens et al. 1996, Tracy \& Christian 1996, Melville \& SChulte 2001, SeARs 2005). In lizards, thermoregulatory behavior and microhabitat selection are correlated because the thermal microclimates vary in space (BARTLETt \& Gates 1967, Roughgarden et al. 1981, Mella 2007), promoting intra and interspecific differences (MARQueT et al. 1989, AdolPh 1990, CorTés et al. 1992, Hertz et al. 1994, Verrastro \& Bujes 1998, Labra et al. 2001, 2008, LABRA \& VIDAL 2003).

In most animal groups, sexual differences in morphological characters (sexual dimorphism) is a common phenomenon, particularly in body size. The direction of this difference, i.e., whether males or females are larger, differs between animal groups; in vertebrates males typically constitute the sex with larger body size (Schoener et al. 1982, Shine 1986, Fairbairn 1990,
1997, ANDERSSON 1994). Several proximate mechanisms have been proposed to explain sexual dimorphism, such as differential mortality of sexes (STAMPS 1993) and different growth rates of sexes (WATKINS 1996); however, natural or sexual selection remains the ultimate mechanism explaining sexual dimorphism (SHINe 1986, ANDERSON 1994, WatKIns 1998). In species with sexual dimorphism, thermal behavior and microhabitat use have many ecological implications due to the displacement of sexes to favorable or unfavorable thermal sites (SCHEERs \& VAN DAMME 2001, VIDAL et al. 2002) or they may determine a highly variable daily pattern (WINNE \& KeCK 2004, RADDER et al. 2005).

Phymaturus palluma (Molina, 1782) is a high-mountain, ovoviviparous, saxicolous and herbivorous lizard (DONOSO-BARROS 1966, LAMBorot \& Navarro 1984) that inhabits niches between $31^{\circ} \mathrm{S}$ and $38^{\circ} \mathrm{S}$ in Chile (Donoso-Barros 1966, VIDAL 2008). This lizard is exposed to harsh environments with cold and snowy winters and it hibernates throughout the winter and part of spring and autumn (DoNOSO-BARRos 1966), which is a particular thermal strategy to enable it to withstand these environments. Phymaturus palluma shows sexual size dimorphism (HABIT \& ORTIZ 1994), and during the reproductive season (November to March, 
IBARGÜENGOYTÍA 2008) it forms hierarchic systems in which dominant males have a more extensive home range than females and juveniles (Habit \& OrTIZ 1996a,b). The spatial segregation in $P$. palluma may reflect differences in thermal strategies (VIDAL et al. 2002, LABRA et al. 2008) because males would have access to better resources than females and juveniles. To understand the behavioral and physiological thermal mechanisms used by $P$. palluma in response to spatial segregation, we analyzed intersexual and age differences in daily activity patterns. If the rigorous environment exerts selection pressure on the thermoregulatory traits in this species, and if also dimorphism determines the quality of the microhabitat used, then we expect to find that males and females have differences in their thermoregulatory ability. We expect that females and juveniles, being at a thermal disadvantage compared to males, will be more efficient in the use of space and in their thermoregulatory ability.

\section{MATERIAL AND METHODS}

The study was performed during November-March (austral spring and summer) in 1986-1987 and in 2002-2004 in Laguna del Laja National Park, Chile $\left(37^{\circ} 20^{\prime} \mathrm{S}, 7^{\circ} 18^{\prime} \mathrm{W}, 1700\right.$ m.a.s.l.). To investigate the activity patterns of $P$. palluma, we established linear transects during the entire daily activity period of lizards (08:30 to 20:30 h). These transects were walked in opposite directions to minimize the probability of repeated counts of the same individual. For each lizard observed, sex, age class, and time of day were recorded. Additionally, one hundred and seven lizards (56 females and 51 males) were collected and thermal data were recorded. Upon capture, the following temperatures were recorded: body (cloacal, $\left.\mathrm{T}_{\mathrm{b}}\right)$, air $(10 \mathrm{~cm}$ above the substrate, $\mathrm{T}_{\mathrm{a}}$ ), and substrate (in contact with the surface, $\mathrm{T}_{\mathrm{s}}$ ) with

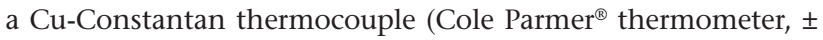
$0.1^{\circ} \mathrm{C}$ ). Sex and body size (snout-vent length, SVL) were recorded for each lizard. Body classes were defined as juveniles (males and females: 48.7-64.0 mm), subadults (males: $65.0-84.0 \mathrm{~mm}$ and females: $65.0-80.0 \mathrm{~mm}$ ) and adults (males: $>84.0 \mathrm{~mm}$ and females: >80.0 mm) according to HABIT \& OrTIZ (1996a).

Differences in SVL between sexes and age classes were analyzed by two-way Analysis of Variance (ANOVA), followed by HSD-Tukey tests (ZAR 1999). Prior to ANOVA, homogeneity of variance and normality were tested by the Levene and Kolmogorov-Smirnov tests, respectively (SoKAL \& RoHLF 1996). A two-way ANCOVA was used to investigate $T_{b}$ differences between sexes and age classes, using SVL as covariate. Variation in daily activity patterns between sexes was analyzed by a G test (ZAR 1999). Data were pooled in four blocks of three hours. The relationship between the frequency of individuals and $\mathrm{T}_{\mathrm{a}}$ and $\mathrm{T}_{\mathrm{s}}$ was analyzed by Pearson correlation (SOKAL \& ROHLF 1996). The thermoregulatory ability was estimated from the variance of $T_{b}$, and from the slopes of the linear regressions (SokAL \& RohlF 1996) between $\mathrm{T}_{\mathrm{b}}$ and $\mathrm{T}_{\mathrm{a}}$ and between $\mathrm{T}_{\mathrm{b}}$ and $\mathrm{T}_{\mathrm{s}}$ (Huey 1982, PerezMellado \& Riva 1993). A slope equal to one indicates that animals are completely thermoconformers (BÁEz \& CoRTés 1990).

\section{RESULTS}

Body size (SVL) differed significantly between sexes $\left(\mathrm{F}_{1,98}=3.55, \mathrm{p}<0.05\right)$ and among age classes $\left(\mathrm{F}_{2,98}=393.57\right.$, $\mathrm{p}<0.001$, Tab. I). All age classes were different (HSD - Tukey tests, $\mathrm{p}<0.001)$. Contrary to the expected, $\mathrm{T}_{\mathrm{b}}$ did not show significant differences between sexes $\left(\mathrm{F}_{1,98}=0.355, \mathrm{p}>0.05\right)$ or among age classes $\left(\mathrm{F}_{2,98}=1.06, \mathrm{p}>0.05\right)$. Lizards had a bimodal daily activity pattern; the frequency recorded in the morning (11:00-13:30 h) was greater than in the afternoon (15:30-18:00 h), and the highest activity was observed at around $25^{\circ}$ to $28^{\circ} \mathrm{C}$ (Fig. 1).

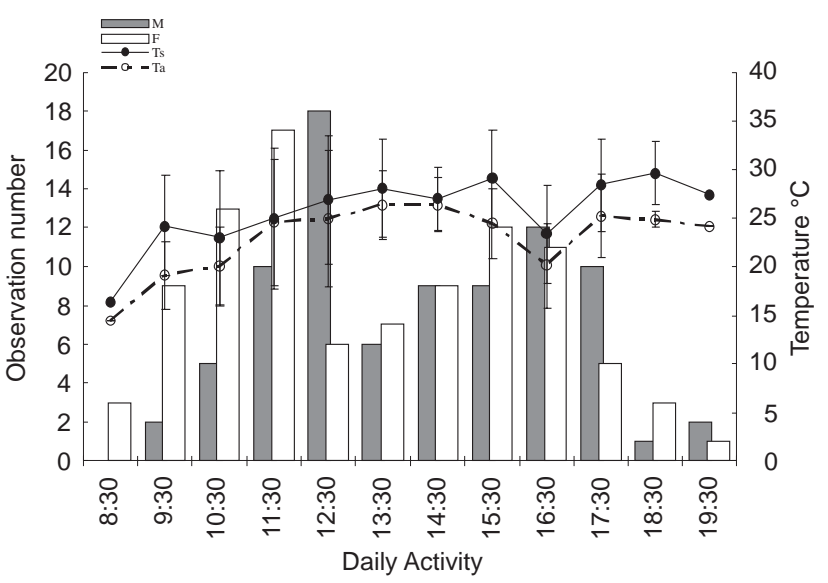

Figure 1. Daily activity pattern of males (black bar) and females (white bar) of Phymaturus palluma. Mean values and standard deviation of air temperature $\left(T_{a^{\prime}}\right.$ dashed line) and substrate temperature $\left(T_{s^{\prime}}\right.$ solid line) are indicated.

The number of lizards observed at different times of day varied significantly. Females emerged earlier than males, when $\mathrm{T}_{\mathrm{a}}$ and $\mathrm{T}_{\mathrm{s}}$ had not exceeded $20^{\circ} \mathrm{C}\left(\chi^{2}=10.6, \mathrm{p}<0.05\right)$, whereas males were only active when the temperature was about $27^{\circ} \mathrm{C}$ (12:30-13:30 and 16:00-17:00 h). The frequency of individuals was positively correlated with $\mathrm{T}_{\mathrm{a}}-\mathrm{T}_{\mathrm{s}}$ (Figs 2 and 3 ). Furthermore, significant relationships were found between $\mathrm{T}_{\mathrm{b}}$ and $\mathrm{T}_{\mathrm{a}}$ (Fig. 4) and between $\mathrm{T}_{\mathrm{b}}$ and $\mathrm{T}_{\mathrm{s}}$ (Fig. 5). The thermoregulatory ability estimated showed that $P$. palluma is a thermodependent species because the slopes were positively related.

\section{DISCUSSION}

Thermal behavior and microhabitat selection are usually correlated with the spatial and temporal variability in thermal resources (Porter et al. 1973, Labra \& Vidal 2003). Phymaturus palluma showed a high thermoconformism, although many species that occur in highly fluctuating habitats are thermoregulators (Vidal et al. 2002, Ibarguengoytía 2005). This species has activity patterns limited in time and a long hibernation period due to being exposed to extreme seasonal changes. Energetic 

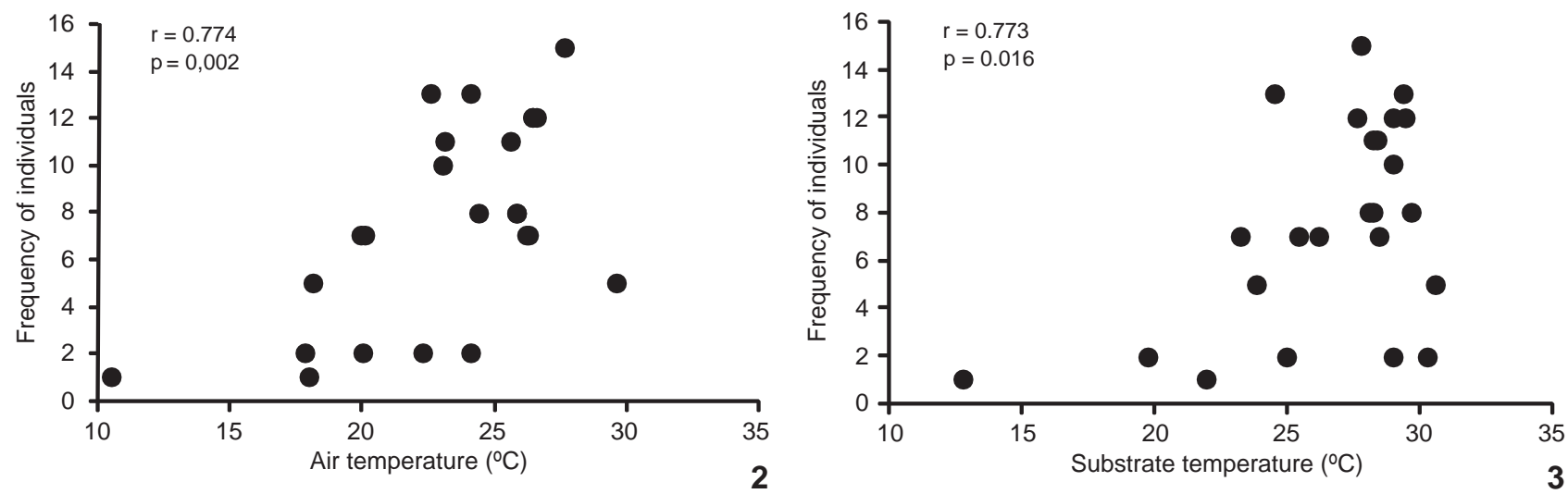

Figures 2-3. Frequency of lizards in relation to (2) air temperature and (3) substrate temperature in Phymaturus palluma.
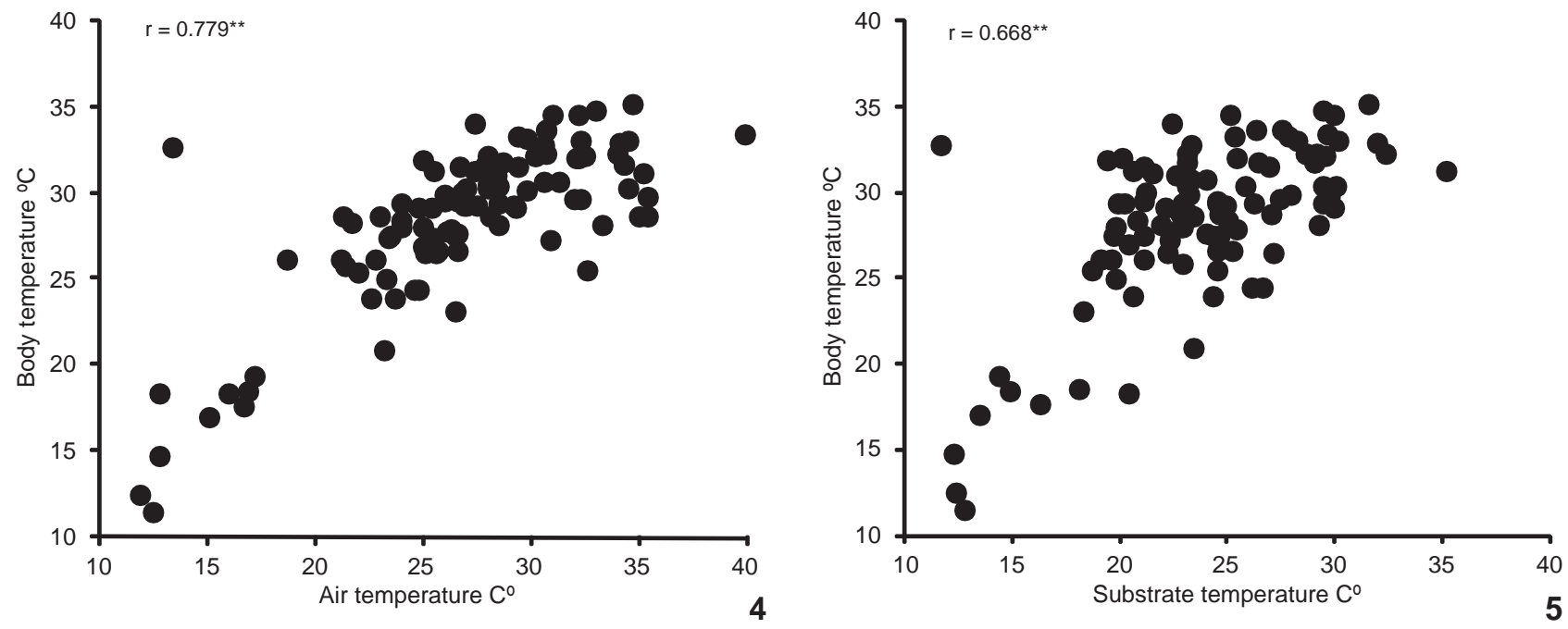

Figures 4-5. Relationship between (4) body and air temperature $\left(T_{b}-T_{a}\right)$, and (5) body and substrate temperature $\left(T_{b}-T_{s}\right)$ in Phymaturus palluma. $r$ and $p<0.01$ are indicated by **.

Table I. Descriptive statistics (mean \pm standard deviation) of body size - snout-vent length (SVL, mm), body temperature (Tb), air temperature (Ta) and substrate temperature (Ts) of females and males of different age classes for P. palluma. (n) Sample size.

\begin{tabular}{lllcccc}
\hline Age classes & Sex & $\mathrm{n}$ & $\mathrm{SVL}$ & $\mathrm{Tb}$ & \multicolumn{2}{c}{ Ta } \\
\hline Adults & Females & 28 & $90.3 \pm 3.6$ & $27.4 \pm 4.8$ & $25.9 \pm 5.7$ & $23.3 \pm 4.4$ \\
& Males & 31 & $91.4 \pm 4.9$ & $28.7 \pm 4.8$ & $26.5 \pm 5.0$ & $24.8 \pm 4.3$ \\
Subadults & Females & 13 & $70.8 \pm 4.1$ & $28.6 \pm 2.2$ & $29.0 \pm 5.5$ & $24.1 \pm 4.7$ \\
& Males & 8 & $72.1 \pm 3.5$ & $30.9 \pm 5.3$ & $24.1 \pm 6.7$ & $25.2 \pm 4.5$ \\
Juveniles & Females & 13 & $56.8 \pm 6.4$ & $28.8 \pm 5.1$ & $27.2 \pm 6.5$ & $23.8 \pm 5.1$ \\
& Males & 11 & $57.1 \pm 5.4$ & $29.4 \pm 5.0$ & $26.6 \pm 6.2$ & $22.6 \pm 5.4$ \\
\hline
\end{tabular}

costs are high in these cases, forcing individuals to maintain body temperature near the temperature of the environment (Cruz et al. 2009). These ecological constraints may be compensated by behavioral thermoregulation (Hertz \& Huey 1981,
Van Damme et al. 1989, Lemos-Espinal \& Ballinger 1995, Huey et al. 2003). It is well known that lizards from cooler habitats can compensate the high cost of thermoregulation by increasing basking time and using microhabitats differentially (HeRTz \& 
Huey 1981, Christian et al. 1983, Dunham et al. 1989, Adolph \& Porter 1993, 1996, Bauwens et al. 1996). Additionally, lizards can change body posture and/or body orientation to the sun (BAuwens et al. 1996, GVo•Dík 2002), and change activity patterns (VAN Damme et al. 1989, Bauwens et al. 1996).

Phymaturus palluma showed a clear sex difference in activity patterns, but not in $\mathrm{T}_{\mathrm{b}}$. The overall, mean body temperature of $P$. palluma was $29^{\circ} \mathrm{C}$. This temperature is similar to that reported by Ibarguengoytía (2005) for $P$. patagonicus Koslowsky, 1898 although Labra \& Vidal (2003) reported temperatures around $22^{\circ} \mathrm{C}$ for $P$. palluma. They pointed out that the low body temperature is a consequence of constraints to thermoregulation. In this context, $P$. palluma was found basking on rocks with the body surface exposed to the substrate. This may indicate that heat surface accounts for a greater percentage of body temperature variance, and suggests a predominantly thigmotherm behavior such as that found in P. patagonicus (IBARGÜENGOYTía 2005).

Body temperature is often influenced by activity time (PAulissen 1999) and the daily thermal cycle (Winne \& KeсK 2004) to maximize prey ingestion, digestive efficiency, reproduction and growth (IBARgüEngoytía 2005). We found that P. palluma lizards had a bimodal daily activity pattern and most individuals were active between 11:00-13:30 and between 15:30-18:00 h. In general, lizards are cool in the early morning just after they emerge from their refuges and warm up at different rates until they have reached the body temperature at which they will remain active for the rest of the day (Habit \& OrTIz 1996b, Paulissen 1999, Ibarguengoytía 2005, Labra et al. 2008). We did not find variation in $\mathrm{T}_{\mathrm{b}}$ among age classes; the hierarchical social behavior of $P$. palluma (HABIT \& OrTIZ 1994) could imply changes in microhabitat use and the time spent, however, this was not determined in the field.

Several studies have pointed out that skin color in lizards plays an important role in thermoregulation, because darker reptiles are able to warm faster and maintain higher body temperatures (CRISP et al. 1979, BITTNER et al. 2002, LUTTERSCHMidT et al. 2003, RANDRIAMAHAZO \& Mori 2005). In many vertebrates, males tend to be more colorful than the females, particularly during the reproductive season (COOPER et al. 1983, COOPER 1988, WATKINS 1997), whereas females tend to have the same colors as the substrate, decreasing the risk of predation, especially during pregnancy (ENdler 1978, CoOper \& Greenberg 1992, ANDERson 1994, Watkins 1997, CuAdrado 2000, Macedonia et al. 2000). Males and females of $P$. palluma showed sexual dimorphism in color pattern and morphology. In fact, females are darker and more flattened than males (Donoso-BArros 1966), thus they increase their area-volume relationship, being able to gain heat faster than the males. This agrees with IBARguENGoyTía (2005) who suggested that females of $P$. patagonicus have a greater control over heating than males, indicating some physiological control over heat gain and loss. On the other hand, the intersexual differences in daily activity patterns may be explained because dominant males have to patrol an extensive home range to maintain the harem (Ferguson 1970, Waldschmidt \& Tracy 1983). In addition, an extensive home range allows them to have access to a greater availability of thermal microhabitats for foraging activities than the females and juveniles (Scheers \& VAN DAMme 2001, VIDAL et al. 2002). Thus, females must display activities earlier to diminish the pressure of dominant males on microhabitat selection (Bauwens et al. 1996, Melville \& Schulte 2001). Females emerge earlier than males, possibly to occupy favorable microhabitats and increase a thermal opportunity for thermoregulatory behavior. Although our results did not show age class differences in $\mathrm{T}_{\mathrm{b}}$, a clear temporal niche separation between males and females is obvious in P. palluma. The hierarchical social behavior of this lizard appears to influence intraspecific differences in microhabitat selection and in the time spent engaging in thermoregulatory behavior and foraging activities (LABRA et al. 2008).

In conclusion, our data support the hypothesis that daily activity patterns differ among sexes but not among age classes in $P$. palluma. Sex differences may probably be due to the hierarchical social system that induces mainly behavioral adjustments for thermal processes. We suggest that $P$. palluma uses a wide display of behaviors (but not physiological regulation) that allows individuals to thermoregulate above the ambient temperature, as has been found for $P$. patagonicus in Argentina (Ibarguengoytía 2005). According to Stevenson (1985), behavioral mechanisms contribute to changes in $\mathrm{Tb}$ that may be four to five times greater than those provided by physiological mechanisms. This is because behavior is seemingly more plastic than physiology.

\section{ACKNOWLEDGEMENTS}

We thank to Hector Ibarra-Vidal by the field assistance. This study was partly funded by NSF PIRE 05-533 to EH and PV and DIUC 205.113.067-1sp of the Universidad de Concepción.

\section{LITERATURE CITED}

AdolPh, S. 1990. Influence of behavioral thermoregulation on microhabitat use by two Sceloporus lizards. Ecology 7: 315327.

Adolph, S. \& W. Porter. 1993. Temperature activity and lizard life histories. American Naturalist 142: 273-295.

Adolph, S. \& W. Porter. 1996. Growth, seasonality, and lizard life histories: age and size at maturity. Oikos 77: 267-278.

Anderson, M. 1994. Sexual selection. Princeton, Princeton University Press, 599p.

Avery, R.A. 1982. Field studies of body temperatures and thermoregulation, p. 167-211. In: C. GANs \& F.H. Pough (Eds). Biology of Reptilia. New York, Academic Press, 536p.

BÁez, C. \& A. Cortés. 1990. Precisión de la termorregulación conductual del lagarto neotropical Tropidurus quadrivittatus (Lacertilia: Iguanidae). Revista Chilena de Historia Natural 63: 203-209. 
Bartlett, P. \& D. Gates. 1967. The energy budget of a lizard on a tree trunk. Ecology 48: 315-322.

Bauwens, D.; P. Hertz \& A. Castilla. 1996. Thermorregulation in a lacertid lizard: the relative contributions of distinct behavioral mechanisms. Ecology 77: 1818-1830.

BitTner, T.D.; R.B. King \& J.M. Kerfin. 2002. Effects of body size and melanism on the thermal biology of garter snakes (Thamnophis sirtalis). Copeia 2002: 477-482.

Christian, K.A.; C.R. Tracy \& W. Porter. 1983. Seasonal shifts in body temperature and use of microhabitats by Galapagos land iguanas (Conolophus pallidus). Ecology 64: 463-468.

Cooper, W. 1988. Scelorporus undulatus consobrinus (southern praire lizard) coloration. Herpetological Review 19: 34.

Cooper, W. \& N. Greenberg. 1992. Reptilian coloration and behavior, p. 298-422. In: C. Gans \& D. Crews (Eds). Biology of the Reptilia, physiology and behavior. Chicago, University of Chicago Press, 423p.

Cooper, W.; C. Adams \& J. Dobie. 1983. Female color change in the keeled earless lizard, Holbrookia propinqua, relationship to the reproductive cycle. Southwest Naturalist 28: 275-280.

Cortés, A.; C. Báez; M. Rosenmann \& C. Pino. 1992. Dependencia térmica del teiido Callopistes palluma: una comparación con los iguánidos Liolaemus nigromaculatus y L. nitidus. Revista Chilena de Historia Natural 65: 443-451.

Crisp, M.; L.M. Cook \& F.V. Hereward. 1979. Color and heat balance in the Lizard Lacerta dugesii. Copeia 1979: 250-257.

Cruz F.B.; L. Belver; J.C. Acosta; H.J. Villavicencio; G. Blanco \& M.G. Canovas. 2009. Thermal biology of Phymaturus lizards: evolutionary constraints or lack of environmental variation? Zoology 112: 425-432.

CUADRADO, M. 2000. Body colours indicate the reproductive status of female common chameleons: experimental evidence for the intersex communication function. Ethology 106: 79-91.

Donoso-Barros, R. 1966. Reptiles de Chile. Santiago, Ediciones Universidad de Chile, 458p.

Duham, A.; B. Grant \& K. Overall. 1989. Interfaces between biophysical and physiological ecology and the population ecology of terrestrial vertebrate ectotherms. Physiological Zoology 62: 335-355.

ENDLER, J. 1978. A predator's view of animal color patterns. Evolutionary Biology 11: 319-364.

FaIRBAirn, D. 1990. Factors influencing sexual size dimorphism in temperate waterstriders. American Naturalist 136: 61-86.

FAIRBAIRN, D. 1997. Allometry for sexual size dimorphism: pattern and process in the coevolution of body size in males and females. Annual Review of Ecology and Systematics 28: 659-687.

FERguson, G. 1970. Matting behavior of the side-blotched lizards of the genus Uta (Sauria: Iguanidae). Animal Behavior 18: 65-72.

Gvo•Dík, L. 2002. To heat or to save time?. Thermoregulation in the lizard Zootoca vivipara (Squamata: Lacertidae) in different thermal environments along an altitudinal gradient. Canadian Journal of Zoology 80: 479-492.

Habit, E. \& J.C. Ortiz. 1994. Ámbito de hogar de Phymaturus flagellifer (Reptilia, Tropiduridae). Boletín de la Sociedad de Biología (Concepción) 65: 149-152.

Habit, E. \& J.C. Ortiz. 1996a. Ciclo reproductivo de Phymaturus flagellifer (Reptilia, Tropiduridae). Boletín de la Sociedad de Biología (Concepción) 65: 149-152.

Habit, E. \& J.C. Ortiz. 1996b. Patrones de comportamiento y organización social de Phymaturus flagellifer (Reptilia, Tropiduridae), p. 141-154. In: J.E. Péfaur (Ed.). Herpetología Neotropical. Mérida, Universidad de los Andes, Consejo de Publicaciones, 451p.

Hertz, P.E. \& R.B. Huey. 1981. Compensation for altitudinal changes in the thermal environment by some Anolis lizards on Hispaniola. Ecology 62: 515-521.

Hertz, P.; L. Fleishman \& C. Armsby. 1994. The influence of light intensity and temperature on microhabitat selection in two Anolis lizards. Functional Ecology 8: 720-729.

Hertz, P.; R. Huey \& R. Stevenson. 1993. Evaluating temperature regulation by field-active ectotherms: the fallacy of the inappropiate question. American Naturalist 142: 796-818.

Huey, R.B. 1982. Temperature, physiology, and the ecology of reptiles, p. 25-91. In: C. Gans \& F.H. PougH (Eds) Biology of Reptilia. New York, Academic Press, 536p.

Huey, R.B. \& M. Slatkin. 1976. Cost and benefits of lizard thermoregulation. Quarterly Review of Biology 51: 363-384.

Huey, R.B.; P.E. Hertz \& B. Sinervo. 2003. Behavioral drive versus behavioral inertia in evolution: a null model approach. American Naturalist 161: 357-366.

IbARGÜENGoyTía, N.R. 2005. Field, selected body temperature and thermal tolerance of the syntopic lizards Phymaturus patagonicus and Liolaemus elongates (Iguania: Liolaemidae). Journal of Arid Environmental 62: 435-448.

Koslowsky, J. 1898. Enumeración sistemática y distribución de los reptiles argentinos. Revista Museo La Plata 8: 161-200.

Labra, A. \& M.A. Vidal. 2003. Termorregulación en reptiles: un veloz pasado y un futuro lento, p. 207-224. In: F. Bozinovic (Ed.). Fisiología Ecológica y Evolutiva. Teoría y Casos de Estudio en Animales. Santiago, Ediciones Universidad Católica de Chile, 531p.

Labra, A.; M. Soto-Gamboa \& F. Bozinovic. 2001. Behavioral and physiological thermorregulation of Atacama desert-dwelling Liolaemus lizards. Ecoscience 8: 413-420.

Labra, A.; M.A. Vidal; R. Solis \& M. Penna. 2008. Ecofisiología de anfibios y reptiles, p. 483-516, In: M.A. VIDAL \& A. Labra (Eds). Herpetología de Chile. Santiago, Science Verlag, 593p.

Lamborot, M. \& J. Navarro. 1984. Karyotypes and sex determination in Phymaturus flagellifer Molina (Iguanidae). Herpetologica 40: 258-264.

Lemos-Espinal, J.A. \& R.E. Ballinger. 1995. Comparative thermal ecology of the high-altitude lizard Sceloporus grammicus on the eastern slope of the Iztaccihuatl volcano, Puebla, Mexico. Canadian Journal of Zoology 73: 2184-2191. 
LutTerschmidt, D.I; W.I. Lutterschmidt \& V.H. Hutchison. 2003. Melatonin and thermoregulation in ectothermic vertebrates: a review. Canadian Journal of Zoology 81: 1-13

Macedonia, J.M.; S. James; L.W. Wittle \& D. Clark. 2000. Skin pigments and coloration in the jamaican radiation of Anolis lizards. Journal of Herpetology 34: 99-109.

Marquet, P.; J.C. Ortíz; F. Bozinovic \& F. JaKsic. 1989. Ecological aspects of thermorregulation at high altitudes: the case of Andean Liolaemus lizards in northern Chile. Oecologia 81: 16-20.

Mella, J. 2007. Reptiles en el Monumento Natural El Morado (Región Metropolitana, Chile): abundancia relativa, distribución altitudinal y preferencia por rocas de distinto tamaño. Gayana 71: 16-26

Melville, J. \& J. Schulte II. 2001. Correlates of active body temperatures and microhabitat occupation in nine species of central Australian agamid lizards. Austral Ecology 26: 660-669.

MolinA, G.I. 1782. Saggio sulla Storia Naturale del Chili. Stamperia di S. Tommaso d'Aquino, Bologne, 368p.

Paulissen, M.A. 1999. Thermal biology of the parthenogenetic whiptail lizards of the Cnemidophorus laredoensis complex (Sauria: Teiidae) in Southern Texas. Texas Journal of Science 51: 37-48.

Perez-Mellado, V. \& I. De la Riva. 1993. Sexual dimorphism and ecology: the case of a tropical lizard, Tropidurus melanopleurus (Sauria: Tropiduridae). Copeia 1993: 969-976.

Porter, W. \& D. Gates. 1969. Thermodynamic equilibria of animals with environment. Ecological Monograph 39: 245-270.

Porter, W.; J. Mitchell; W. Beckman \& C. DeWitt. 1973. Behaviorals implications of mechanistic ecology. Oecologia 13: 1-54.

Radder, R.S.; S.K. Saidapur \& B.A. Shanbhag. 2005. Population density, microhabitat use and activity pattern of the Indian rock lizard, Psammophilus dorsalis (Agamidae). Current Science 89: 560-566

Randriamahazo, H.J.A. \& A. Moki. 2005. Factors affecting the intra-populational variation in dorsal color pattern of an Iguanian lizard, Oplurus cuvieri cuvieri. Current Herpetology 24: 19-26.

Roughgarden, J.; W. Porter \& D. Heckel. 1981. Resource partitioning of space and its relationship to body temperature in Anolis lizard population. Oecología 50: 256-264.

Scheers, H. \& R. VAn Damme. 2001. Micro-scale differences in thermal quality and a possible case of evolutionary flaxibility in the thermal physiology of lacertid lizards. Oecologia 132: 323-331.

Schoener, T.; J. Slade \& C. Stinson. 1982. Diet and sexual dimorphism in the very catholic lizard genus, Leiocephalus, of the Bahamas. Oecologia 53: 160-169.

SEARS, M.W. 2005. Geographic variation in the life history of the sagebrush lizard: the role of thermal constraints on activity. Oecologia 143: 25-36.
Seebacher, F. \& C.E. Franklin. 2005. Physiological mechanisms of thermoregulation in reptiles: a review. Journal of Comparative Physiology B 175: 533-541.

Shine, R. 1986. Sexual differences in morphology and niche utilization in an aquatic snake, Acrochordus arafurae. Oecologia 69: 260-267.

SokAL, R. \& F.J. Rohlf. 1996. Biometry: the principles and practice of Statistics in Biological Research. New York, W.H. Freeman, 773p.

Stamps, J.A. 1993. Sexual size dimorphism in species with asymptotic growth after maturity. Biological Journal of the Linnean Society 50: 123-145.

STEVENSON, R.D. 1985. The relative importance of behavioral and physiological adjustments controlling body temperature in terrestrial ectotherms. American Naturalist 126: 362-386.

Tracy, R. \& K. Christian. 1996. Ecological relations among space, time, and thermal niche axis. Ecology 67: 609-615.

Van Damme, R.; D. Bauwens; A.M. Castilla \& R.F. Verheyen. 1989. Altitudinal variation of the thermal biology and running performance in the lizard Podarcis tiliguerta. Oecologia 80: 516-524.

Verrastro, L. \& C. Bujes. 1998. Rhythm of activity of Liolaemus occipitalis (Sauria, tropiduridae). Revista Brasileira de Biologia 15: 913-920.

VIDAL, M. 2008. Biogeografía de anfibios y reptiles, p. 195-231. In: M.A. Vidal \& A. Labra (Eds). Herpetología de Chile. Santiago, Science Verlag, 593p.

Vidal, M.; J.C. Ortiz \& A. Labra. 2002. Sexual and age differences in ecological variables of the lizard Microlophus atacamensis (Tropiduridae) from Northern Chile. Revista Chilena de Historia Natural 75: 283-292.

WALDSChMidT, S. \& R. TRACy. 1983. Interactions between a lizard and its thermal environment: implications for sprint performance and space utilization in the lizard Uta stansburiana. Ecology 64: 476-484.

Watkins, G.G. 1996. Proximate causes of sexual size dimorphism in the Iguanian lizard Microlophus occipitalis. Ecology 77: 1473-1482.

Watkins, G. 1997. Intersexual signalling and the functions of female coloration in the Tropidurid lizard Microlophus occipitalis. Animal Behavior 53: 843-852.

Watkins, G.G. 1998. Function of a secondary sexual ornament: the crest in the South American iguanian lizard Microlophus occipitalis (Peters, Tropiduridae). Herpetologica 54: 161-169.

Winne, C.T. \& M.B. Keck. 2004. Daily activity patterns of Whiptail Lizards Squamata: Teiidae: Aspidoscelis: a proximate response to environmental conditions or an endogenous rhythm? Functional Ecology 18: 314-321.

ZAR, J. 1999. Biostatistical analysis. New Jersey, Prentice Hall, $663 p$.

Submitted: 04.III.2009; Accepted: 18.I.2010.

Editorial responsibility: Kleber del Claro

ZOOLOGIA 27 (1): 13-18, February, 2010 